\title{
Sudden death associated with Niedenzuella stannea (Malpighiaceae) in cattle in the State of Mato Grosso, Brazil: importance and epidemiological aspects ${ }^{1}$
}

\begin{abstract}
Flávio H.B. Caldeira², Geovanny B.G. Dias², Felipe P. de Arruda², Valdecy de M. Lourenço ${ }^{3}$, Kalinne S. Bezerra ${ }^{2}$, Franklin Riet-Correa ${ }^{4}$ and Edson Moleta Colodel $^{5 *}$

ABSTRACT.- Caldeira F.H.B., Dias G.B.G., Arruda F.P., Lourenço V.M., Bezerra K.S., Riet-Correa F. \& Colodel E.M. 2017. Sudden death associated with Niedenzuella stannea (Malpighiaceae) in cattle in the State of Mato Grosso, Brazil: importance and epidemiological aspects. Pesquisa Veterinária Brasileira 37(7):662-666. Departamento de Clínica Médica Veterinária, Faculdade de Agronomia, Medicina Veterinária e Zootecnia, Universidade Federal de Mato Grosso, Campus Universitário, Av. Fernando Corrêa da Costa 2367, Bairro Boa Esperança, Cuiabá, MT 78069-900, Brazil. E-mail: moleta@ufmt.br

The aim of this study was to investigate the importance of an acute disease that was characterized by sudden death associated with exercise that affected cattle in the region of the Araguaia River, especially in the municipality of Torixoréu, southeastern Mato Grosso, Brazil. Between August and September 2013, eighty farms in the municipality were visited and the pastures of these farms were inspected. Epidemiological questionnaires were completed from 65 farms. A plant identified as Niedenzuella stannea ( $N$. stannea) of the Malpighiaceae family was attributed to the cause of sudden death in cattle, what causes major economic losses. Sudden death reports have occurred since 1970, when livestock was introduced into the region, and sudden death reports still occur. Outbreaks were reported to occur from May to October, but mainly during the dry season between June and August. N. stannea was identified at 41 farms and was always found in near to rivers. The most effective plant control methods included plowing the pastures and fields followed by manual application of Tordon ${ }^{\circledR}$ (Picloram and 2.4D). The administration of $5 \mathrm{~g} / \mathrm{kg}$ of young leaves which were collected from a farm with a sudden death history in cattle also caused sudden death in a sheep. Thus, it is concluded that the sudden death of cattle in the region of the Araguaia River is caused by the consumption of N. stannea.
\end{abstract}

INDEX TERMS: Poisonous plants, toxic plants, Niedenzuella stannea, Malpighiaceae, plant poisoning, sudden death, cattle, experimental poisoning, sheep, Mato Grosso.

\footnotetext{
${ }^{1}$ Received on September 7, 2016.

Accepted for publication on August 2, 2017.

${ }^{2}$ Programa de Pós-Graduação em Ciências Veterinárias, Faculdade de Agronomia, Medicina Veterinária e Zootecnia (Famevz), Universidade Federal de Mato Grosso (UFMT), Av. Fernando Corrêa da Costa 2367, Bairro Boa Esperança, Cuiabá, MT 78068-900, Brazil.

${ }^{3}$ Instituto de Defesa Agropecuária do Estado de Mato Grosso (Indea/ MT), Rua Bela Vista s/n, Centro, Torixoreu, MT 78260-000, Brazil.

${ }^{4}$ Laboratório de Anatomia Patológica, Hospital Veterinário, Centro de Saúde e Tecnologia Rural (CSTR), Universidade Federal de Campina Grande, Patos, PB 58700-310, Brazil.

${ }^{5}$ Departamento de Clínica Médica Veterinária (Climev), Faculdade de Agronomia, Medicina Veterinária e Zootecnia (Famevz), Universidade Federal de Mato Grosso (UFMT), Campus Universitário, Av. Fernando Corrêa da Costa 2367, Bairro Boa Esperança, Cuiabá, MT 78069-900, Brazil. *Corresponding author: moleta@ufmt.br
}

RESUMO.- [Morte súbita associada a Niedenzuella stannea (Malpighiaceae) em bovinos no Estado de Mato Grosso: importância e investigação epidemiológica.] 0 objetivo deste trabalho é relatar a investigação sobre uma enfermidade de caráter agudo, caracterizada por morte súbita associada ao exercício, que acomete bovinos na região de bacias hidrográficas do Rio Araguaia, especialmente no município de Torixoréu, sudeste do estado de Mato Grosso, Brasil. Entre agosto e setembro de 2013, foram visitadas e inspecionadas as pastagens em 80 propriedades rurais do município, e em 65 aplicado um questionário epidemiológico. Uma planta identificada como Niedenzuella stannea (Malpighiaceae), é incriminada como causadora de morte súbita em bovinos gerando grandes prejuízos econômicos. 
Relatos de morte súbita datam desde 1970, quando a pecuária começou a ser inserida na região, e ocorrem até os dias atuais. Surtos ocorreram em diferentes meses do ano, variando de maio a outubro, sendo a maior parte concentrada durante o período de seca, especialmente nos meses de junho a agosto. $N$. stannea foi identificada em 41 propriedades, sendo presente próxima aos leitos de rios. Os métodos de controle da planta relatados como mais eficazes foram o arar da pastagem e roça manual seguida da aplicação de Tordon ${ }^{\circledR}$ (Picloram e 2,4D). A administração para um ovino, de $5 \mathrm{~g} / \mathrm{kg}$ de folhas em brotação de $N$. stannea, coletadas em uma propriedade com histórico de morte súbita em bovinos, reproduziu o quadro de morte súbita. Conclui-se que as mortes súbitas em bovinos em áreas da bacia hidrográfica do rio Araguaia se devem ao consumo de N. stannea.

TERMOS DE INDEXAÇÃO: Plantas tóxicas, Niedenzuella stannea, Malpighiaceae, intoxicação por plantas, morte súbita, bovinos, intoxicação experimental, ovino, Mato Grosso.

\section{INTRODUCTION}

Sudden death is important in livestock in Brazil because it is responsible for at least half of the cattle deaths caused by the consumption of plants in the country (Tokarnia et al. 2012). The major plants associated with this type of poisoning belong to three families: Rubiaceae, Bignoniaceae and Malpighiaceae (Tokarnia et al. 2012). In the Malpighiaceae family, Amorimia septentrionalis and A. rigida stand out as the most important toxic plants in the Northeast (Tokarnia et al. 1990, 2012, Duarte et al. 2013), whereas A. exotropi$c a$ is the most important toxic plant in the South (Gava et al. 1998, Pavarini et al. 2011) and A. sepium in the North (Schons et al. 2011); however, considering the geographic location of the outbreaks in Brazil and photo identification, Lee et al. 2012 suggested that the species is probably $A$. Amazonica. Poisonings by A. pubiflora in the Midwest and Southeast have also been reported (Tokarnia \& Döbereiner 1973, Becker et al. 2013).

Numerous plant species that cause sudden death in livestock contain the toxic organofluorine compound monofluoroacetate (MFA) (Lee et al. 2012), which decreases the production of ATP and blocks other metabolic processes that are dependent on energy (Clarke 1991). In cattle, the primary effects occur in the heart and cause sudden death (Maxie \& Robinson 2007). In most cases, clinical signs and death are precipitated by exercise (Lemos et al. 2011, Tokarnia et al. 2012, Becker et al. 2013); but the occurrence of poisoning depends on many factors such as palatability, hunger, sprouting after the first rains, and dose and toxicity variations (Pessoa et al. 2013).

The aim of this study was to investigate the importance of an acute disease characterized by sudden death associated with exercise, which affects cattle in the region of the Araguaia River, especially in the municipality of Torixoréu in the southeastern region of the State of Mato Grosso, Brazil.

\section{MATERIALS AND METHODS}

Epidemiologic study. A descriptive observational study was conducted by selecting cattle farms located in regions with a sud- den death history; these cattle farms were identified by the Office of Agricultural Protection of Mato Grosso (Indea/MT) in the

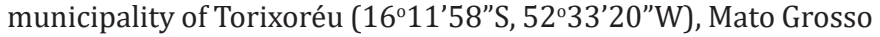
(MT), midwestern Brazil. The farms were located in the Araguaia-Tocantins River Basin on the banks of the Araguaia River and its tributaries including the Diamantino River and the main tributaries of Diamantino, Guariroba and Quebra-Dente Creeks. GPS TrackMaker software, version 13.8 .517 was used to obtain the geographical coordinates of the farms after the properties bordering these rivers were selected using Google Earth ${ }^{\mathrm{TM}}$, version 7.0.8415. The properties were systematically visited to distribute the epidemiological questionnaire, to inspect the pastures and mark the location using a global positioning system (GPS).

The epidemiological survey was given to the owners and employees of the farms to collect data regarding the characteristics of the farms, outbreaks of sudden death and mortality control. A modified model of forms 2 and 3 used by Silva et al. (2006) was used. Photos published by Tokarnia et al. (2012) of the main plants that cause sudden death in Brazil were shown to the interviewed subjects for possible recognition of these plants in the region.

Collection of plant samples. Samples were collected of only the species that were suggested by the interviewed subjects as causing the disease and that were found on farms where the occurrence of sudden death in cattle was frequent. Leaf, fruit and flower samples collected in November 2012 from a farm that was visited $\left(16^{\circ} 18^{\prime} 41.38^{\prime \prime} \mathrm{S}, 52^{\circ} 56^{\prime} 01.77^{\prime \prime} \mathrm{W}\right)$ were sent to the University of Michigan Ervaarium (Michigan, USA) for botanical identification.

Experimental poisoning. Sprouting leaf samples of a similar plant that were sent for identification were orally administered to a male sheep at a dose of $5 \mathrm{~g} / \mathrm{kg}$ body weight (bw). Six hours after administration of the plant, the sheep was forced to run. After the exercise, a clinical examination was performed including monitoring of respiratory movements, behavior, posture and consumption of water and food. At necropsy, gross lesions were recorded, and samples of the liver, kidney, heart, lung, intestine, lymph nodes, spleen and brain were collected. The samples were fixed in $10 \%$ formalin, routinely processed for histology, and stained with hematoxylin and eosin for histologic evaluation. All animal research was approved by the Ethical Committee in the Use of Experimental Animals of the Federal University of Mato Grosso (CEUA-UFMT) (protocol 23108016273/13-0).

\section{Botanical identification}

The plant that was suspected to cause sudden death in the rural area of the municipality of Torixoréu was identified as the species Niedenzuella stannea (Griseb.) W.R. Anderson, which belongs to the Malpighiacea family.

\section{Epidemiologic study}

Eighty farms in the municipality of Torixoréu were visited, and all the pastures were inspected. Of these farms, people were available to answer the epidemiological questionnaire on 65 farms. Of the respondents, 40 (61.53\%) were owners, 17 (26.15\%) were cowherds, five (7.69\%) were managers, and three $(4.61 \%)$ performed general services. From the 65 properties where interviews were performed, $33(50.76 \%)$ reported a history of sudden death among cattle. The oldest reports date back to 1970 when livestock activity began in the region, and currently deaths are still reported. The main clinical signs reported by the respondents had a common relationship with the move- 
ment of cattle, in which parties described the following clinical signs: rough hair coat, frequent urination, trembling, weakness, drooling, falling and dying quickly. Respondents often associated the death of the animal with the arrival at the barn (described as barn odor).

The outbreaks occurred in different months of the year, ranging from May to October and mainly during the dry season between June and August. Respondents reported that when the dry period of the year starts, the pastures and other invasive plants begin to "dry", and Niedenzuella stannea begins to sprout in this period. This plant was described to be more visible or even the only "green" plant in the pasture. During this time, the cattle begin to consume the plant, and mortality begins. N. stannea was attributed by all respondents to be responsible for causes of sudden death in cattle. Of the 33 farms with a history of sudden death, all respondents reported the occurrence of $N$. stannea. In seven of these properties, the plant has been eradicated, and recognition was confirmed by the photos. None of the plants presented in the photos, including plants in the Rubiaceae or Bignoniaceae family known to cause sudden death in cattle, were recognized by respondents or found during a survey of the pasture areas or surrounding forests.

Forms of disease control were reported in all of the properties and included plant control and control of the manifestation of the intoxication. Regarding plant control, the most effective management method, which eradicated the plant, was to plow the pastures infested with $N$. stannea (on two properties) or cutting followed by the application of Tordon ${ }^{\circledR}$ (Picloram + 2.4D) (on five properties). Some respondents claimed that manual weeding increased the occurrence of poisonings due to regrowth of the plant, which is more attractive to cattle. On properties where the plant was not controlled, some owners prevented animal access to the plants by surrounding these areas (i.e., fencing). $\mathrm{Ow}$ ners often reported that when they needed to use the area with $N$. stannea present, they put the calves (weanlings) in these areas because the mortality of young animals would cause less economic damage.

The control of the manifestation of intoxication was focused on management practices. As the clinical signs mostly occurred after the movement of cattle, constant handling was avoided, except for obligatory vaccinations. However, this management method creates access to pastures that contain $N$. stannea during free pasture; the cattle arrive in the free pastures and remain there for a period of five to 15 days. After this time, management practices are performed.

The mortality related to the consumption of $N$. stannea reported by the respondents showed variation with rates of $0.2 \%$ to $8 \%$ of the herd each year. In addition, some animals recovered, but there were no precise rates of morbidity. This research reported that at least 573 cattle and one buffalo died based on the presentation of sudden death in the last 43 years and on the different properties.

\section{Inspection of pastures}

Inspection of the pastures was performed on 80 farms in the municipality of Torixoréu, Mato Grosso. The aim

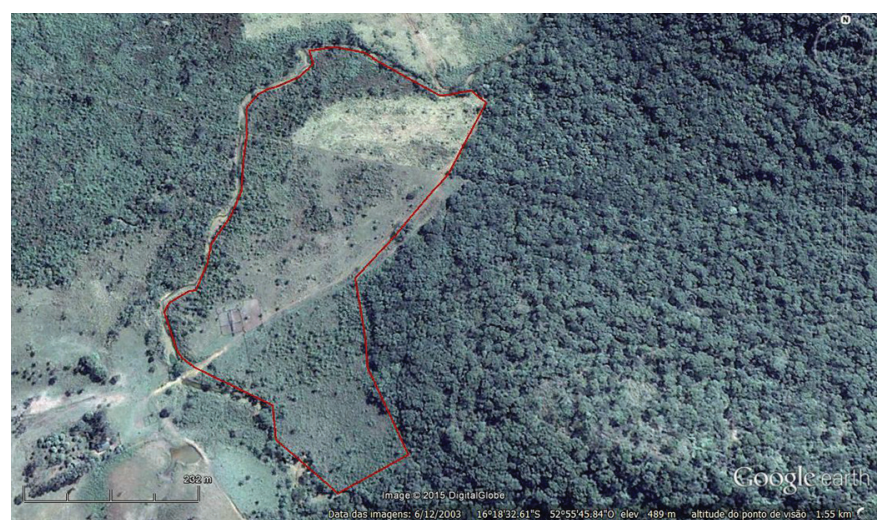

Fig.1. Independence Farm, Torixoréu, Mato Grosso, Brazil. (A) Green Niedenzuella stannea in a pasture of dry Brachiaria spp. (B) Cattle consuming leaves of N. stannea in August 2013. (C) Sprouts of N. stannea. (D) Flowers and fruits of N. stannea.

of the inspection was to identify known toxic plants that cause sudden death and the presence of the plant that respondents termed "Erva". This "Erva" plant was identified on 41 properties in the region (Fig.1) and it was exclusively present on properties that border the main rivers of the municipality, namely, the Guariroba, Quebra-Dente, Diamantino and Araguaia Rivers (Fig.2). The plant was observed to infest areas next to the banks of rivers and close to riparian forests, and it was also found in areas of dense forest but in areas no more than 500 meters from the riverbanks. The respondents described that the plant can only be developed where the land is more favorable for agriculture. This visit occurred during the month of August, and there was abundant flowering and fruiting of the species incriminated by respondents as responsible for causing sudden death in cattle. No case of spontaneous poisoning was observed during the visits. Palicourea marcgravii, Amorimia pubiflora or other plant species known to cause sudden death in livestock were not observed during these surveys and were not mentioned during the questioning.

\section{Experimental poisoning}

For the experimental poisoning, six hours after the administration of $5 \mathrm{~g} / \mathrm{kg}$ bw of leaves, the sheep was forced to run for two minutes, and the following clinical signs were noted: muscle spasm, paddling movements, tachycardia, engorgement of the jugular, positive venous pulse, opisthotonos and nystagmus. The sheep died within five minutes after the fall. A necropsy was performed and revealed a diffusely congested lung and the presence of foam in the trachea. Engorgement of the cranial vena cava and petechiae in the pericardium were also observed. No significant microscopic changes were observed.

\section{DISCUSSION AND CONCLUSIONS}

In Brazil, Niedenzuella stannea is found in the Amazon and Pantanal regions and has a geographical distribution in the states of Pará, Mato Grosso and Mato Grosso do Sul (Mamede 2014). The genus Niedenzuella, previously classified in the genus Mascagnia and Tetrapterys, presents morpholo- 


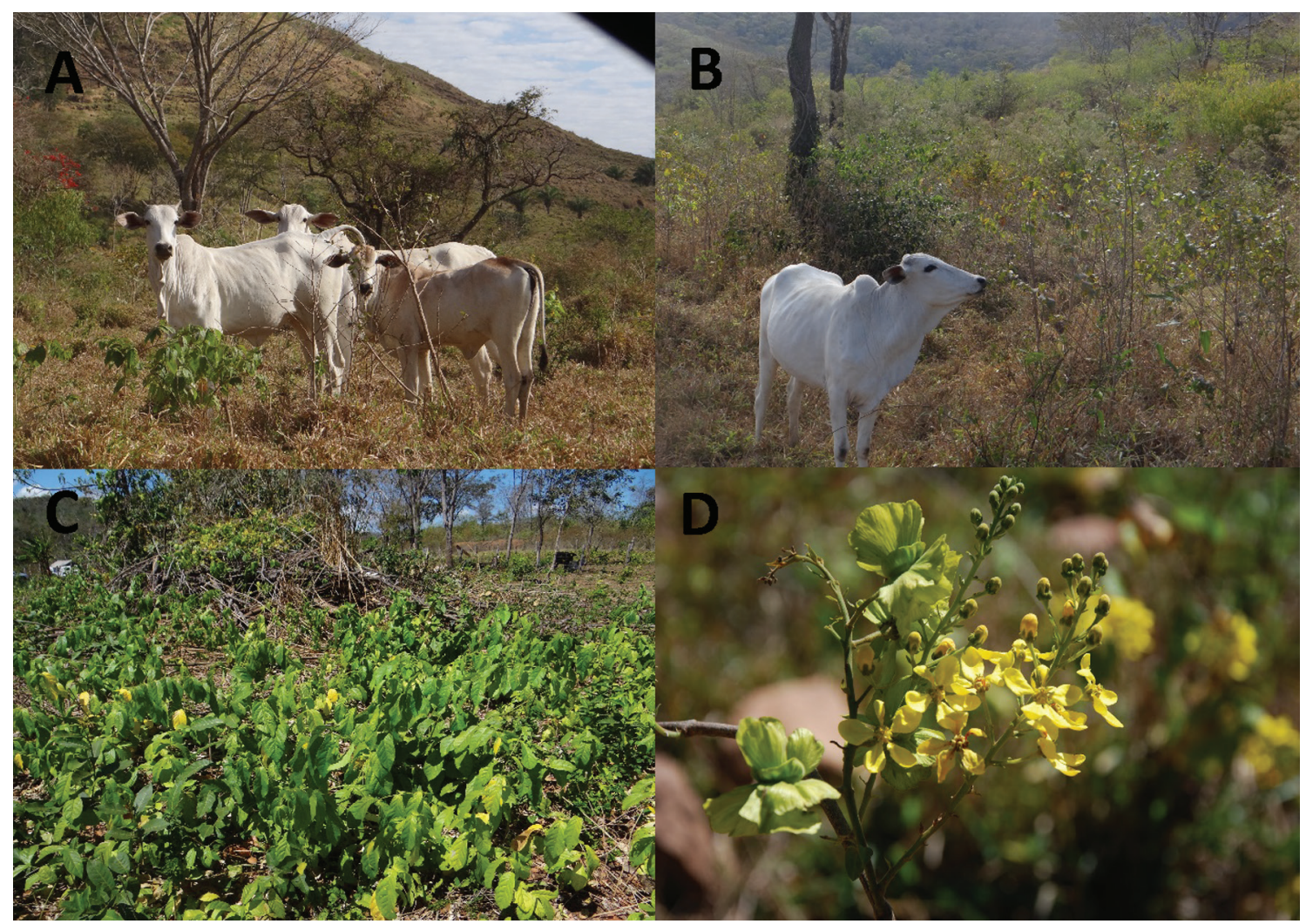

Fig.2. Bacuri Farm, Torixoréu, Mato Grosso. The demarcated area near the Quebra-Dente River (circled in red) was infested by Niedenzuella stannea up to $307 \mathrm{~m}$ from the river bank.

gical characteristics similar to the other species of Malpighiaceae (Anderson 2006). Although many Malpighiaceae species are known to be toxic to cattle, there are no previous reports in the literature indicating poisoning by $N$. stannea.

This epidemiological survey showed that the plant popularly called "Erva", which was identified as Niedenzuella stannea, is the cause of sudden death in cattle in the municipality of Torixoréu, MT. Evidence showed that mortality was present only in pastures where $N$. stannea was found. Reductions of mortality occurred with plant control, and sudden death cases ceased when the plant was eradicated. Additionally, in this study, sudden death was reproduced with the administration of $N$. stannea to a sheep. In addition to these factors, other plants that cause sudden death, such as Palicourea marcgravii (Tokarnia \& Döbereiner 1986) and Albuquerque et al. 2014, pubiflora (Becker et al. 2013), which cause poisoning in the Midwest Region of Brazil, were not found during the inspection of the pastures. Using photo identification, none of the respondents recognized Palicourea marcgravii, but Amorimia spp. was often identified as "Erva", which may have been due to the morphological similarity between the plants (Anderson 2006).

Poisoning by $N$. stannea was most often related to bovine species. The most visited properties had horses that grazed in common areas more than cattle, but there was no record of sudden death or other evidence indicating intoxication in horses. One property reported an occurrence of sudden death in a buffalo that grazed in the pastures with
N. stannea. Reports of sudden death in buffaloes associated with plant consumption are infrequent. Barbosa et al. (2003) reported that this species is up to six times more resistant to poisoning by Palicourea marcgravii.

The infestation by $N$. stannea in the pastures was found close to the riverbanks including riparian forests. This plant was also found in distant and dense forest areas, but it was limited to a distance of less than 500 meters from the riverbanks. Respondents reported that the plant grows only where the land is more favorable for agriculture. These features have also been described in other Malpighiaceae, such as Amorimia pubiflora, which inhabits fertile soils, and A. rigida and A. Amazonica, which grow in areas close to rivers (Schons et al. 2011, Tokarnia et al. 2012).

Difficulty in controlling and eradicating some species of Malpighiaceae such as A. pubiflora (Becker et al. 2013), $A$. rigida and $A$. septentrionalis is a common characteristic of these plants (Tokarnia et al. 2012, Albuquerque et al. 2014), which may be related to the fact that they have a deep root system that facilitates regrowth. The economic impact of the control of this disease related to the consumption of $N$. stannea cannot be calculated as there is no accurate information on the cost to reform pastures, of labor and the purchase of pesticides. Generally, the owners complained about the high costs of this control. Among the most effective poisoning control measures reported by respondents were soil plowing and manual cutting followed by application of a product that contains picloram 2.4 D., but the economic costs of this method can inhibit its prac- 
tice, especially in large areas and in areas with high infestation. The report indicates that the majority of owners used, due to costs, techniques that control the manifestation of clinical poisoning such as proper handling of the animals and resting in an area free of $N$. stannea. Some people reported that they prefer to let younger cattle graze in pastures infested by the plant because it reduces the economic impact of mortality. Manual cutting that is used to control the infestation has proven inefficient due to the occurrence of more intensified regrowth.

The death of 573 cattle was used to calculate the direct costs of mortality by Niedenzuella stannea poisoning. Considering an average body weight of $300 \mathrm{~kg}$ at US\$ $2.40 \mathrm{per}$ kg (IMEA 2015), the cost attributed to the death of cattle by poisoning on these farms where interviews occurred would equate to US\$206.280. However, this number is clearly underestimated as this information was obtained from people currently on the farm during the interview and excluded data from previous owners or employees. For a better understanding of poisoning by N. stannea, experimental studies must be conducted to analyze the clinical and pathological effects and the technical and economic viability of control methods for this plant.

Acknowledgements.- The authors are grateful toDr. William R.Anderson, University of Michigan Herbarium, Ann Arbor, Michigan, USA, for botanic identification and to Mato Grosso State Research (FAPEMAT-Proc. 156883/2014) and the National Institute of Science and Technology for the Control ofPlantpoisonings(INCT/CNPq) for financial support.

\section{REFERENCES}

Albuquerque S.S.C., Rocha B.P. \& Almeida V.M. 2014. Fibrose cardíaca associada à intoxicação por Amorimia septentrionalis em bovinos. Pesq. Vet. Bras. 34(5):433-437.

Anderson W.R. 2006. Eight segregates from the neotropical genus Mascagnia (Malpighiaceae). Novon 16:168-204.

Barbosa J.D., Oliveira C.M.C., Tokarnia C.H. \& Riet-Correa F. 2003. Comparação da sensibilidade de bovinos e búfalos à intoxicação por Palicourea marcgravii (Rubiaceae). Pesq. Vet. Bras. 23(4):167-172.

Becker M., Caldeira F.H.B., Carneiro F.M., Oliveira L.P., Tokarnia C.H., RietCorrea F., Lee S.T. \& Colodel E.M. 2013. Importância da intoxicação por Amorimia pubiflora (Malpighiaceae) em bovinos em Mato Grosso: reprodução experimental da intoxicação em ovinos e bovinos. Pesq. Vet. Bras. 33(9):1049-1056.
Clarke D.D. 1991. Fluoroacetate and fluorocitrate: mechanism of action. Neurochem. Res. 16(9):1055-1058.

Duarte A.L., Medeiros R.M.T. \& Riet-Correa F. 2013. Intoxicação por Amorimia spp. em ruminantes. Ciência Rural 43(7):1294-1301.

Gava A., Cristani J., Branco J.V., Neves D.S., Mondadori A.J. \& Souza R.S. 1998. Mortes súbitas em bovinos causadas pela ingestão de Mascagnia sp. (Malpiguiaceae) no Estado de Santa Catarina. Pesq. Vet. Bras. 18(1):16-20.

IMEA 2015. Instituto Mato-grossense de Economia Agropecuária, Cuiabá, MT. <http://www.imea.com.br/cotacoes. php? produto=4\&subproduto= 21> Accessed August 2015.

Lee S.T., Cook D., Riet-Correa F., Pfister J.A., Anderson W.R., Lima F.G. \& Gardner D.R. 2012. Detection of monofluoroacetato in Palicourea and Amorimia species. Toxicon 60:791-796.

Lemos R.A.A., Guimarães E.B., Carvalho N.M., Nogueira A.P.A., Santos B.S., Souza R.I.C., Cardinal S.G. \& Kassab H.O. 2011. Plant poisonings in Mato Grosso do Sul, p.68-72. In: Riet-Correa F., Pfister J., Schild A.L. \& Wierenga T. (Eds), Poisoning by Plants, Mycotoxins, and Related Toxins. CAB International, Wallingford, UK.

Mamede M.C.H. 2014. Niedenzuella in: Lista de Espécies da Flora do Brasil. Jardim Botânico do Rio de Janeiro. <http://reflora.jbrj.gov.br/jabot/floradobrasil/FB101449> Accessed May 2014.

Maxie M.G. \& Robinson W.S.F. 2007. Cardiovascular system, p.1-105. In. Maxie M.G. (Ed.), Jubb, Kennedy, and Palmer's Pathology of Domestic Animals. Vol.3. 5th ed. Saunders Elsevier, Philadelphia. 737p.

Pavarini S.P., Soares M.P., Bandarra P.M., Gomes D.C., Bandinelli M.B., Cruz C.E.F. \& Driemeier D. 2011. Mortes súbitas em bovinos causadas por Amorimia exotropica (Malpighiaceae) no Rio Grande do Sul. Pesq. Vet. Bras. 31:291-296

Pessoa C.R.M., Medeiros R.M.T. \& Riet-Correa F. 2013. Importância econômica, epidemiologia e controle das intoxicações por plantas no Brasil. Pesq. Vet. Bras. 33(6):752-758

Schons S.V., Mello T.L., Riet-Correa F. \& Schild AL. 2011. Poisoning by Amorimia (Mascagnia) septiumin sheep in northern Brazil. Toxicon 57:781786.

Silva D.M., Riet-Correa F., Medeiros R.M.T. \& Oliveira O.F. 2006. Plantas tóxicas para ruminantes no Seridó Ocidental e Oriental do Rio Grande doNorte. Pesq. Vet. Bras. 26:223-236.

Tokarnia C.H. \& Döbereiner J. 1973. Intoxicação por Mascagnia pubiflora em bovinos no Estado do Mato Grosso. Pesq. Agropec. Bras. 8:61-68.

Tokarnia C.H. \& Döbereiner J. 1986. Intoxicação por Palicourea marcgravii (Rubiaceae) em bovinos no Brasil. Pesq. Vet. Bras. 6:73-92.

Tokarnia C.H., Peixoto P.V. \& Döbereiner J. 1990. Poisonous plants affecting heart function of cattle in Brazil. Pesq. Vet. Bras. 10:1-10.

Tokarnia C.H., Brito M.F., Barbosa J.D., Peixoto P.V. \& Döbereiner J. 2012. Plantas Tóxicas do Brasil para Animais de Produção. 2aㅡ ed. Editora Helianthus, Rio de Janeiro. 